\title{
Rhythmanalysis of Life during Physical Distancing for Covid-19: Sri Lankans in Brussels, Belgium
}

\author{
Koen De Wandeler, Rishika Mariella Mendis, \\ Sonya Milanthi Nanayakkara, Mahishini Vasudevan \\ KU Leuven Faculty of Architecture, Campus St. Lucas Brussels, BELGIUM \\ Corresponding Author: Koen De Wandeler; E-mail- koen.dewandeler@kuleuven.be
}

\begin{abstract}
This paper presents case studies of Sri Lankans who were confined in lockdown in the Brussels Capital Region (BCR) during the first wave of the COVID-19 pandemic. It does so through research that Sri Lankan students produced within the framework of an explorative study conducted from March until May 2020. The study revolved around an exercise in rhythmanalysis as part of a course on Urban Anthropology at the KU Leuven Faculty of Architecture. It involved 73 Master students as well as the respective respondents that each of them had selected among their countrymen residing in the BCR. The assignment was to document how the COVID-19 pandemic evolved in Belgium and their home country, to observe how that progression affected residents' behaviour and public life in both contexts, and to record what usage the respondents made of social media to stay in touch with people back home.

The first section of this paper reviews Lefebvre's rhythmanalysis theory and various ways in which it has been interpreted over the years. The second section describes how the theory was applied within the said Urban Anthropology course, how the methodology of the 2020 assignment was adapted to the COVID-19 context and what contextual information emerged from the amalgamated research outputs. The next three sections specify how the three Sri Lankan students handled the assignment. One reiterates the progression of the COVID-19 situation in the BCR and Colombo based on media reports and the students' participant observation in public life. The next presents the students' observations 'as seen from the window' i.e., from the limited perspective they had left on neighbourly life amidst lockdown. A third one details observations derived in collaboration with their respective respondents from recording and examining the respondent's online behaviour over 72 hours.

The last section of the paper assesses how the Sri Lankan observations mesh with overall outcomes of the study and what the research revealed about the level of adaptation that voluntary migrants achieved amidst confinement in the BCR. As part of their final reflections, the authors appraise the added value of the exercise as a whole and of rhytmanalysis as a research tool in particular.
\end{abstract}

Keywords: COVID-19, Rhythmanalysis, Brussels Capital Region, Colombo. 


\section{Introduction}

Within weeks after the Chinese authorities introduced a first lockdown to contain the coronavirus in Wuhan, they had to gradually extend the measure over other regions in China. The World Health Organization (WHO) initially focused its containment efforts on China whilst preparing measures for handling the novel coronavirus in other countries at a country level. By the time WHO declared the new disease a pandemic on $11^{\text {th }}$ March 2020, several countries had restricted air travel, reduced public transportation or banned mass events. Since then, stringent travel restrictions have become the norm rather than the exception. The COVID-19 pandemic has shown, once again, that international migrants are particularly vulnerable to crisis situations. As the corona virus spread across the world, governments introduced measures to 'flatten the curve' of infections. Most of these regulations greatly affected mobility and migration. A slow-down of migration processing and assistance to asylum seekers seriously afflicted those who were forced into migration. Voluntary migrants were also affected by travel restrictions prohibiting entry of residents from other countries. Some countries closed their borders entirely, while in others, labour migration was suspended. This constricted opportunities for education or employment, entailed the possible loss of wages, health insurance coverage as well as remittance flows. Besides lockdowns, both loss of employment, and social distancing forced and voluntary migrants to face xenophobic and discriminatory treatments that exacerbated the pain and loss felt at being apart from loved ones back home.

Confinement seriously constrained observing and documenting the situation but it also boosted creativity in finding alternative ways to conduct and disseminate research. When the Belgian Government announced its first measures against corona, the KU Leuven reacted swiftly by making all education only through digital channels. This became the norm for the rest of the academic year and required the revision of all fieldwork-based assignments, including the study described in this paper.

The study draws on research that was conducted as part of a course on Urban Anthropology in the KU Leuven International Master of Architecture program. The course instructor had adopted the rhythmanalysis theory of Henri Lefebvre as a fixed component of the course since several years. He first used it in a fieldwork project through which international Master students could mirror their understanding of multiculturalism in the BCR with that of country(wo)men who had lived and worked several years in the BCR. Students used rhythmanalysis as a tool to observe and analyze their respondents' rhythms at a socio-cultural as well as at a more personal level. Security concerns after the 2016 bombings in Brussels prompted a shift to rhythmanalytical observations that could be performed in group such as site analyses students conducted for their design studio. All of these exercises had in common that students were required to conduct fieldwork and have face-to-face interactions with the people whose rhythms they were recording. Due to the COVID-19 regulations on confinement and physical distancing, the 2020 rhythmanalytical project had to be converted overnight from a face-to-face field-research into a study that students could conduct online and from the confinement of their home.

In this paper, the instructor of the course joins three Sri Lankan students who took part in the study and report on their observations against the backdrop of the overall outcomes of the study. The first section of the paper reviews Lefebvre's rhythmanalysis theory and various ways in which it has been interpreted over the years. The second section describes how the theory was applied within the said Urban Anthropology course, how the methodology of the 2020 assignment was adapted to the COVID-19 context and what contextual information emerged from the amalgamated research outputs. The next three sections present how the three Sri Lankan students handled the assignment. One reiterates the progression of the COVID-19 situation in the BCR and Colombo based on media reports and the students' participant observation in public life. The next reviews the students' observations 'as seen from the window' i.e., from the limited perspective they had left on neighbourly life amidst lockdown. A third one details observations that the 
students derived in collaboration with their respective respondents after recording and examining the respondent's online behaviour over 72 hours.

The last section assesses how the Sri Lankan observations mesh with overall outcomes of the study and what the research revealed about the level of adaptation that voluntary migrants achieved amidst confinement in the BCR. As part of their final reflections, the authors appraise the added value of the exercise as a whole and of rhythmanalysis as a research tool in particular.

\section{Rhythmanalysis: theory and applications in urban contexts}

Henri Lefebvre's (2004) interest in rhythms stemmed from his life-long aspiration to link up different aspects of daily life which intellectual practice had too often kept separate: time and space, the public and the private realms, the state-political and the personal life-sphere, etc. He saw rhythm as the nexus connecting these diverse aspects. He contended that rhythm occurs whenever there is an interaction between a place, a time and an expenditure of energy. He argued that this interaction is governed by a clock-wise regulated time: a complex of rational rhythms that is overshadowing the multiple natural rhythms of the body (respiration, heartbeat, hunger and thirst, etc.). Taking the human body as a point of departure, he explained the relativity of rhythms: a rhythm is only slow or fast in relation to another rhythm.

Our own body is an astonishing example of polyrhythmia, with each organ following its own rhythm. As long as we are in good health, we take the harmonious interactions between all these rhythms or eurhythmia, for granted. It is only when we are ill and experience arrhythmia - or disruption of our bodily rhythms - that we come to appreciate our body's synergetic vigour. To complement these observations, Lefebvre (2004) also coined the term isorhythmia for the rare occurrences - such as a symphony concert - where synchronization of rhythms reaches a seamless equivalence of repetition, measure and frequency.

The internal synchronicity of bodily rhythms resonates in external polyrhythmia, ranging from the "bundle of rhythms" of other beings, other entities, social life, global events and even the cosmic body. Drawing on Jaulin (1973), Lefebvre therefore distinguished "rhythms of the self" or personally inscribed rites organizing time towards private life and self-presence and "rhythms of the other" that are turned towards representation and public discourse. This seemingly polar opposition is modulated by intermediate levels: "endogenous rhythms" characterize activities performed for and with family, relatives or close friends, whereas "external rhythms" involve activities imposed/performed under external pressure or upon demand by third persons. "Sociocultural rhythms" comprise outward activities which one shares with a larger group of people such as festivals, parades, religious days, commemorative days. The occurence of these rhythms involved ever wider spatial settings such as: "the bedroom, the apartment, the house, the street, the square and the district, finally the town - even the immediate family, the extended family, the neighbourhood, friendly relations and the city" (Lefebvre, 2004:95).

Lefebvre (2004) proclaimed rhythmanalysis - the opening and unwrapping of these distinct but intimately entwined bundles of rhythm - as "a science, a new field of knowledge [savoir]". It uses rhythm as a mode of analysis: a tool rather than just an object of analysis. In order to examine and re-examine temporality, rhythmanalists draw on lived experience and adopt a transdisciplinary approach bringing together widely diverse practices and types of knowledge: sociology, psychology, anthropology, economy, history, climatology, cosmology as well as poetry (the poetic) (Lefebvre, 2004:16). This may explain why rhythmanalysis, as a way of researching space and time together, has appealed to a diverse range of disciplines and how it has been adapted in a variety of fields that seek to elucidate everyday life in the contemporary world.

Dawn Lyon's What is Rhythmanalysis? (2019) offers a thorough review of that full body of work. She notably presents grouping of areas where empirical research using rhythmanalysis is most pronounced. Besides cultural and historical rhythmanalyses, examinations of rhythms of nature and rhythms and mobility, she distinguishes investigations into working rhythms and rhythms of space and place-making. These latter two areas of research are most relevant to the study described 
here. Of particular interest is urban research that was inspired by the Lefebvre's interest in the city as a testing ground for his theory. The third chapter of his essay describes rhythms as "Seen from the Window" set in the center of Paris (Lefebvre, 2004: 27-37). The essay is followed by a description of "The Rhythmanalytical Project" and an "Attempt at the Rhythmanalysis of Mediterranean Cities", both co-authored with Cathérine Régulier (Lefebvre, 2004: 71-100). All three studies confirm not only the importance of clock-wise, mechanistic rhythms in city life, but also how we become more conscious of our rhythms "when we begin to suffer from some irregularity" (Lefebvre, 2004: 77). All irregularity or disruption "throws out of order" and creates a kind of "hole in time" (Lefebvre, 2004:44, italics ibidem) that may be momentarily cause disarray but also hold a creative, transformative potential. The idea that disruption could create a void full of potential was the immediate inspiration for the design of this research assignment.

\section{The 2020 Urban Anthropology research project}

The first wave of coronavirus infections forced Belgium in lockdown from 18 march until 3 May 2020. The confinement largely coincided with the period during which the fieldwork assignment in the Urban Anthropology course had been scheduled. Like earlier batches, the students in the 2020 batch were due to examine how well respondents from the same home country as themselves adjusted to the disruption caused by relocating to and adapting to life in in a multicultural environment like the BCR. And like earlier assignments, the 2020 assignment would rely on a research methodology steeped in Lefebvre's (2004) rhythmanalysis theory. However, the outbreak of the COVID-19 pandemic gave rise to an additional crisis for all involved in the assignment. Due to physical distancing regulations, moreover, the instructor had to rethink the scope of study and adjust the assignment so that students could be collect and process data online and from the confinement of their home.

\subsection{Research questions and methodology}

The study owes its explorative character largely to the alterations that the confinement necessitated. The research focus shifted from examining how students and their countrymen - as representatives of voluntary migrants in the BCR - adapted to the host society to the question how they endured the COVID-19-induced confinement and lockdown away from family and friends back home. Based on the hypothesis that rhythmanalysis offered a valid research tool to investigate this question online, the course instructor devised three research components:

1) The physical distancing induced by the COVID-19 pandemic has largely wiped out longestablished "socio-cultural rhythms". Instead, people's lives around the globe have become regulated by reports on the progression of the pandemic. The first task of the research, therefore, required students to track the COVID-19 situation in the BCR and their respective home-towns. They could do this by monitoring online reports on medical trends, government measures, the level of public obedience, frequency of offenses, mainstream news media and social media reactions, etc.

2) Confinement during the COVID-19 pandemic reduced the life-world of people to their home, allowed them to run the most necessary errands only and meet fewer people. The second task of the research, therefore, was to document how confinement affected daily life for themselves and the people in their immediate surroundings. Following the example set by Lefebvre (2004), students could do this systematically for intervals of 15 minutes each at regular times of the day from the window of their room, the balcony of their residence, and complement these observations with neighbourly exchanges on the news of the day and 'lived experiences' during the occasional errand to the neighbourhood store, the jogging rounds or any other secure place of observation. 
3) The lockdown throughout the research period forced people into online communication for study, work and contact with family and friends. Most students and their respondents were far from home and worried about the situation back home. Therefore, the third task for the students was to establish online rapport with their respondent, draw her/his profile and trace how their pre-Covid-19 contact with home differed from contacts under confinement. Students could do this by establishing their respondents' socio-cultural activities and by asking them to keep a record of their social media usage during three consecutive days (including one weekend-day). After discussing this record with their respondent, students analysed the data by applying Lefebvre's categorization:

- 'socio-cultural rhythms'(i.e. rhythms one performs together with people with whom one share one or more socio-cultural traits)

- 'rhythms of the self' (i.e. rhythms one conducts for one's self)

- 'endogenous rhythms of the other' (i.e. rhythms one conducts in relation to others in one's close circle),

- 'external rhythms of the other' (i.e. rhythms one conducts in relation to people and/or schedules external one's close circle and/or control).

The course instructor also had to pay attention to methodological and logistic peculiarities of the assignment. Only six of the 73 students were Belgians and several of the 67 other students did no longer reside in the BCR but had returned to their home country. This dispersion required precise instructions on data mining and processing as well as an overhaul in the way students' progress could be monitored and coached. Table 1 shows the various situations that required slightly different instructions for data collection and processing depending on the place where students resided during the study.

Moreover, several students were the sole representatives of their country. To spread the coverage somewhat more evenly, the instructor subdivided the group in 11 clusters with regional and cultural affinities (Table 2). This not only facilitated coaching the students online, it also fuelled discussion among students from different countries and benefitted the comparative value of the research. Throughout the data-mining stages of the research, students kept working in groups and reported in online group meetings on their progress. After a progress presentation attended by all regional groups, students began focussing on the third component, work, reporting and coaching became individualised. Individual final submissions completed the study. 
Table 1: Various situations for data mining by foreign students

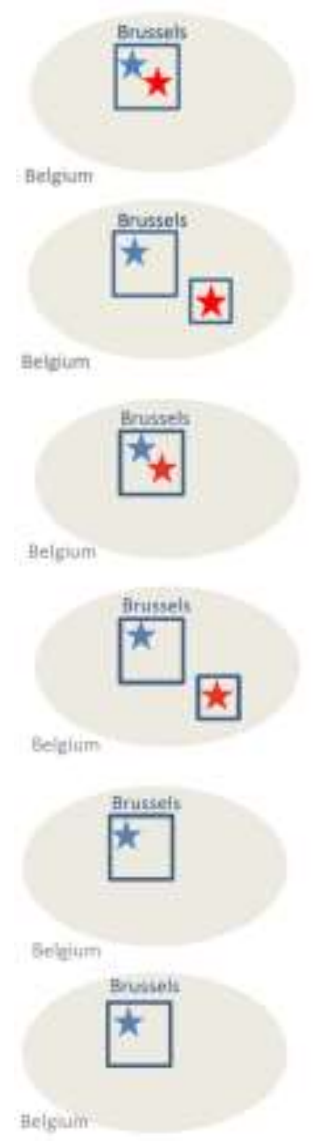

Legend:

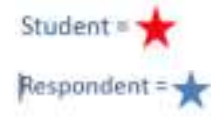

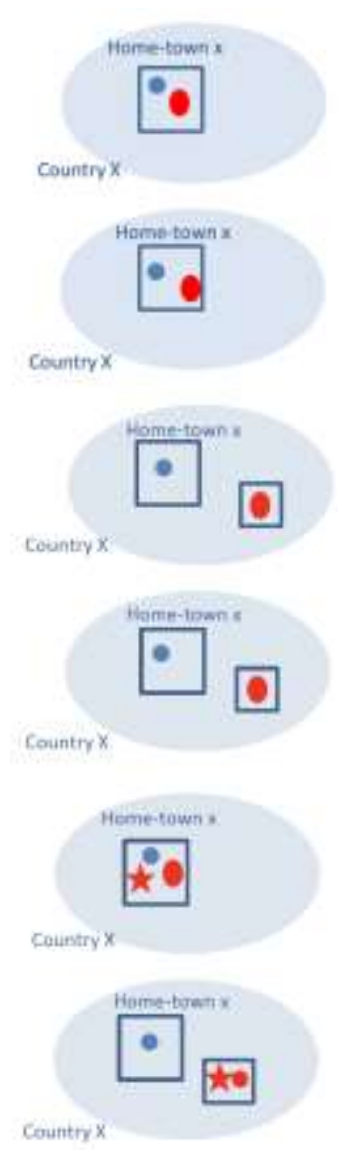

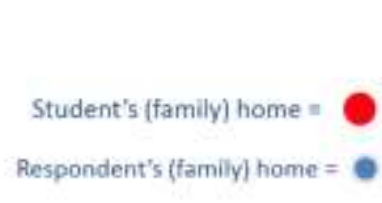

Table 2: Distribution of students in 11 regional groups

\begin{tabular}{|c|c|c|c|}
\hline \multirow{2}{*}{$\begin{array}{l}\text { Geographical } \\
\text { Region }\end{array}$} & \multirow[t]{2}{*}{ Country } & \multicolumn{2}{|c|}{ Nr. of students } \\
\hline & & country & region \\
\hline $\begin{array}{l}\text { Belgium \& immediate } \\
\text { neighbours }\end{array}$ & $\begin{array}{l}\text { Belgium } \\
\text { France } \\
\text { The } \\
\text { Netherlands } \\
\text { U.K. }\end{array}$ & $\begin{array}{l}6 \\
1 \\
1 \\
1\end{array}$ & 9 \\
\hline $\begin{array}{l}\text { Central \& Northern } \\
\text { Europe }\end{array}$ & $\begin{array}{l}\text { Czech } \\
\text { Republic } \\
\text { Denmark } \\
\text { Germany } \\
\text { Finland } \\
\text { Sweden } \\
\end{array}$ & $\begin{array}{l}4 \\
1 \\
2 \\
1 \\
1\end{array}$ & 9 \\
\hline Southern Europe & $\begin{array}{l}\text { Italy } \\
\text { Spain } \\
\text { Switzerland }\end{array}$ & $\begin{array}{l}2 \\
1 \\
3\end{array}$ & 6 \\
\hline Western Balkans & $\begin{array}{l}\text { Albania } \\
\text { Croatia } \\
\text { Kosovo } \\
\text { Slovenia }\end{array}$ & $\begin{array}{l}2 \\
1 \\
2 \\
1\end{array}$ & 6 \\
\hline $\begin{array}{l}\text { South-eastern Europe \& } \\
\text { Turkey }\end{array}$ & $\begin{array}{l}\text { Greece } \\
\text { Hungary } \\
\text { Romania } \\
\text { Turkey }\end{array}$ & $\begin{array}{l}1 \\
1 \\
2 \\
3 \\
\end{array}$ & 7 \\
\hline Middle East & $\begin{array}{l}\text { Egypt } \\
\text { Jordan } \\
\text { Lebanon } \\
\text { Palestine }\end{array}$ & $\begin{array}{l}1 \\
1 \\
3 \\
1 \\
\end{array}$ & 6 \\
\hline Iran \& Oman & $\begin{array}{l}\text { Iran } \\
\text { Oman }\end{array}$ & $\begin{array}{l}8 \\
1\end{array}$ & 9 \\
\hline South Asia & $\begin{array}{l}\text { India } \\
\text { Sri Lanka }\end{array}$ & $\begin{array}{l}4 \\
3\end{array}$ & 7 \\
\hline China & China & 5 & 5 \\
\hline Other Asia & $\begin{array}{l}\text { Indonesia } \\
\text { Taiwan } \\
\text { Thailand } \\
\text { Uzbekistan }\end{array}$ & $\begin{array}{l}1 \\
1 \\
1 \\
1 \\
\end{array}$ & 4 \\
\hline Latin America & $\begin{array}{l}\text { Brazil } \\
\text { Colombia } \\
\text { Ecuador }\end{array}$ & $\begin{array}{l}1 \\
3 \\
1\end{array}$ & 5 \\
\hline TOTAL & $\begin{array}{r}36 \\
\text { countries }\end{array}$ & & 73 \\
\hline
\end{tabular}

\subsection{Background on the confinement in the BCR drawn from the regional study groups}

The overall study reported on the progress of COVID-19 in 36 countries, compiled 73 accounts of students' observations of life under confinement and conducted a rhythmanalysis of three days 'life under confinement in the BCR' among 73 respondents. The following paragraphs summarize these findings as a back drop for the Sri Lankan case studies

\section{- Accounts from students' 'window' on life under confinement in the BCR}

The lockdown in Belgium required people to stay home. Exceptions were granted for personal outdoor exercise, a restricted time for shopping necessary goods and emergency displacements. Since physical distancing was mandatory, digital media became widely used to compensate for the lack of social \& physical interaction. Working from home became the norm. Food delivery services boomed. Online shopping expanded and digital payment methods became widely used. Unfortunately, confinement also bred anxiety and xenophobic reactions, particularly against Asian respondents who were taken for Chinese and by extension, considered as the spreaders of the pandemic. The lockdown period brought about depression, abusive behaviour 
and domestic violence, but on the whole, it begot wide-spread expressions of solidarity and support.

Deprived of handshakes, pats on the back and hugs, colleagues shifted to online afteroffice-hours drinks and families to online apéritif parties. As the hype of this 'new normal' wore off, spring began to warm the air and lengthen the days. Following the example set in Italy and Spain, the inhabitants of the BCR and other Belgian cities took to their front door or balcony to give a one-minute applause in support for frontline health-workers. Neighbours who had never talked before got to know each other and started chatting. Soon, housemates and neighbours began meeting on the doorstep, while their children played in the streets, backyards became animated with barbecues and family gatherings. Larger gatherings remained prohibited and this disrupted but did not stop family celebrations such as mothers' Day, religious celebrations such as Easter, or celebrations cherished by one or more ethnic, linguistic or socio-cultural groups inhabiting the BCR. Several communes of the BCR, for example, have a large Muslim population. During Ramadan, they practiced the traditional fast and daily evening meals in their neighbourhood knowing that the authorities had assigned street educators and peacekeepers to ensure that people did not break physical distancing after Iftar.

\section{- Rhythmanalysis of three days 'life under confinement in the BCR'}

Due to the closing of schools and offices, respondents had to reconfigure their 'external rhythms of others'. Within a very short lapse of time, they had to shift to online platforms for study and work (mostly 'Zoom'), and for seeking out people with a similar socio-cultural background (mostly Facebook and Messenger). Disruptions in public transportation, rules of physical distancing and various measures of confinement further eroded their circle of contacts and social life. Once the awkwardness of confinement was overcome, respondents generally welcomed the shift and re-arranged their usage of time in a way that benefitted the 'rhythms of the self'. Many went through a 'lazy' transition period when they dived into Netflix, Youtube and Instagram. But gradually it became apparent that the sudden availability of time for oneself, away from fellow students, colleagues and buddies, offered an opportunity for reflection and introspection. Making the most of online resources, some respondents launched into meditation or took up new hobbies such as yoga, poetry or handicrafts; others embarked on an intensive, individual program of physical exercise. Pre-occupation with health issues also brought about a renewed interest in traditional medicine and healing methods (homeopathy, Ayurveda, etc.). Social media such as Whatsapp and messenger helped to explore this and similar pursuits with like-minded people. These media platforms also helped to enhance respondents' 'endogenous rhythms of the other' by maintaining regular contact with friends and relatives back home, and holding on to the familiar in the unfamiliar setting of a lockdown in a foreign country. These lifelines were more pronounced for students than for employees. The students were far more focused on events back home, whilst employees were more concerned about the situation - and particularly their job prospects - in the BCR. Irrespective of occupation or length of stay, respondents experienced a need for togetherness when confinement deprived them from socio-cultural rhythms such as family gatherings (10/5 Mothers' Day), national holidays (21/3-2/4 Noroez/Persian New Year; 13-15/4 Thai New Year), national or international remembrance days (27/4 King's day in the Netherlands; 1/5 Labor Day; 8/5 VE Day in the UK; 9/5 Victory Day in Uzbekistan), and religious Days and Festivals (4-16/4 Matsu procession, Taiwan; 12/4 Easter; Ramadan and Eid alFitr 23/4 - 23/5). 


\section{Progression of the Covid-19 pandemic in the BCR and in Colombo until $5^{\text {th }}$ May} 2020

As the research was conducted amid a lockdown, the students took to national news platforms and social media platforms for up-to-date information. They mainly relied on newspaper articles and daily news announcements for collecting reliable data ${ }^{1}$. Table 3 presents a synthesis of the information from these media outlets; an overview of the lockdown taking place in each country.

Table 3: Timeline of COVID-19 progression in Belgium and Sri Lanka Source: Mendis, R.M. (2020), Nanayakkara, S.M. (2020), Vasudevan, M. (2020))

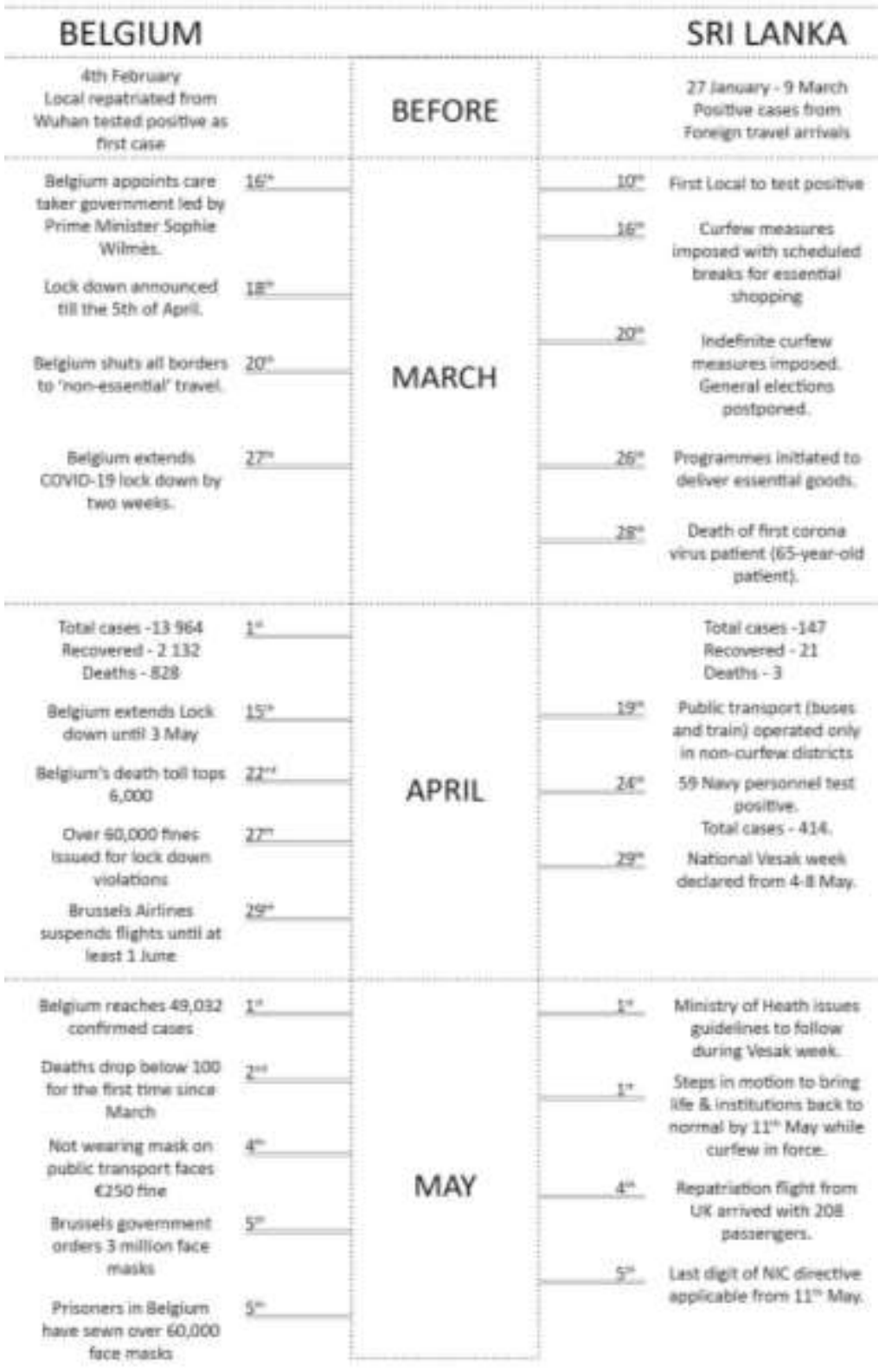

\footnotetext{
${ }^{1}$ Data for Belgium was collected from the online newspaper website Brussels Times and the Worldometers website was used to keep a track of the number of cases; for Sri Lanka, data was collected from the Ada Derana News text alerts.
} 


\section{Participant observation of public life under confinement (and in quarantine)}

"The window overlooking the street is not a mental place, where the inner gaze follows abstract perspectives: a practical space, private and concrete, the window offers views that are more than spectacles; mentally prolonged spaces."

Lefebvre, 2004:33

For the second line of investigation, the three students logged their observations of public life in a way Lefebvre (2004) described in the chapter 'as seen from the window'. This was done to record how the city around them was dealing with the lockdown. Mahisihini and Sonya, made their observations from the confinement of their accommodation and its immediate surroundings in a residential part of Brussels while Rishika, the third student, did so from a temporary quarantine centre in Negombo, Sri Lanka.

\section{- Mahishini and Sonya: public life under confinement as observed in Schaerbeek, BCR}

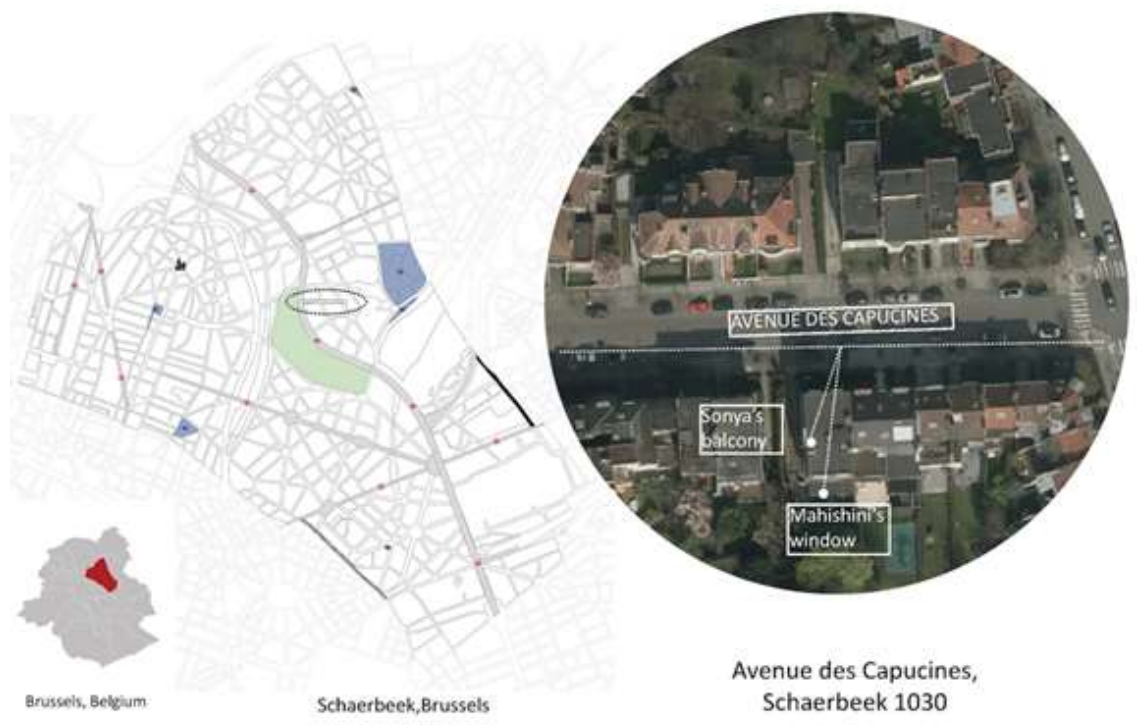

Fig. 1: Location of Mahishini and Sonya's observations.

Mahishini and Sonya lived in Schaerbeek, one of the 19 municipalities in the BCR. The area is predominantly residential with essential services and transport stations within walking distance. Their university campus is located 20 minutes away by foot and the closest public park is 5 minutes away. The neighbourhood comes complete with a church and a few essential stores. The housing block was located next to a major thoroughfare which had a large influx of vehicular movement throughout the day till late evening.

\section{- Mahishini's observations in Schaerbeek}

Mahishini conducted her observations from the window of her room overlooking her landlord's garden and broadened the scope of rhythms by also recording happenings from the balcony of Sonya's room. Observations were conducted on; May 1st (Friday) which was a Week day before lock down measures were relaxed, May $3^{\text {rd }}$ (Sunday) and May $4^{\text {th }}$ (Monday) which was a week day when lock down measures were relaxed. The choice of the specific different days helped to produce more interesting and varied observations. 

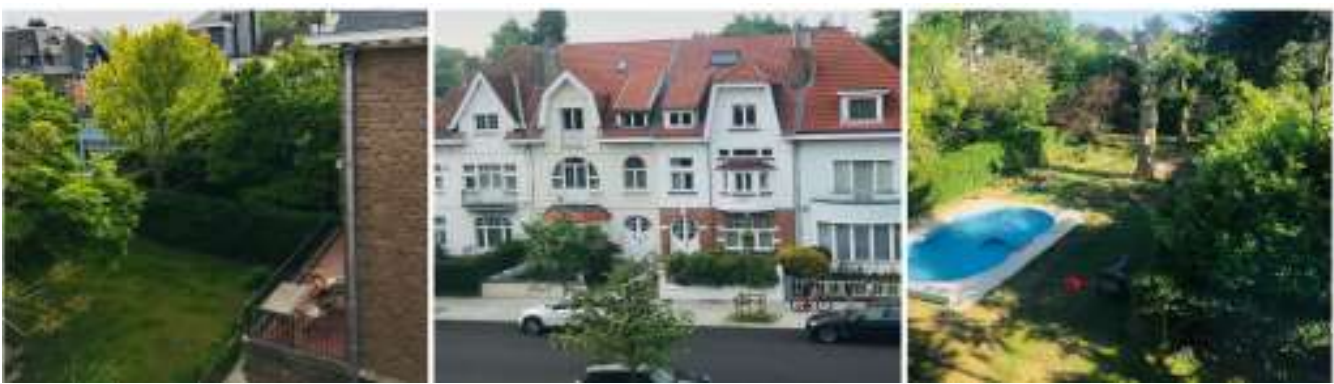

Fig. 2: Views from Balcony (left \& middle) and Garden (Right) Source: Vasudevan, M. (2020)

In the months before the Covid-19 confinement, the street where both students had lived since the start of the academic year, had been calm and quiet, with a light movement of cars. Residents of the area were mostly indoors, with little activity on the streets or sidewalks and even less interactions between neighbours. As the lockdown period progressed, this situation changed. Children began taking over the streets with their cycles or for sports, and neighbours started coming out to interact with one another. The streets and pavements became an important piece of public space that helped people overcome the strict measures and the weariness of staying indoors. On a similar note, the garden too became filled with activity as the family decided to entertain neighbours or gathered to have dinners. The timelines below show the observed activities on both parts: it shows the unchanging constant rhythms that occur every day as well as the new rhythms that found their place in each day.

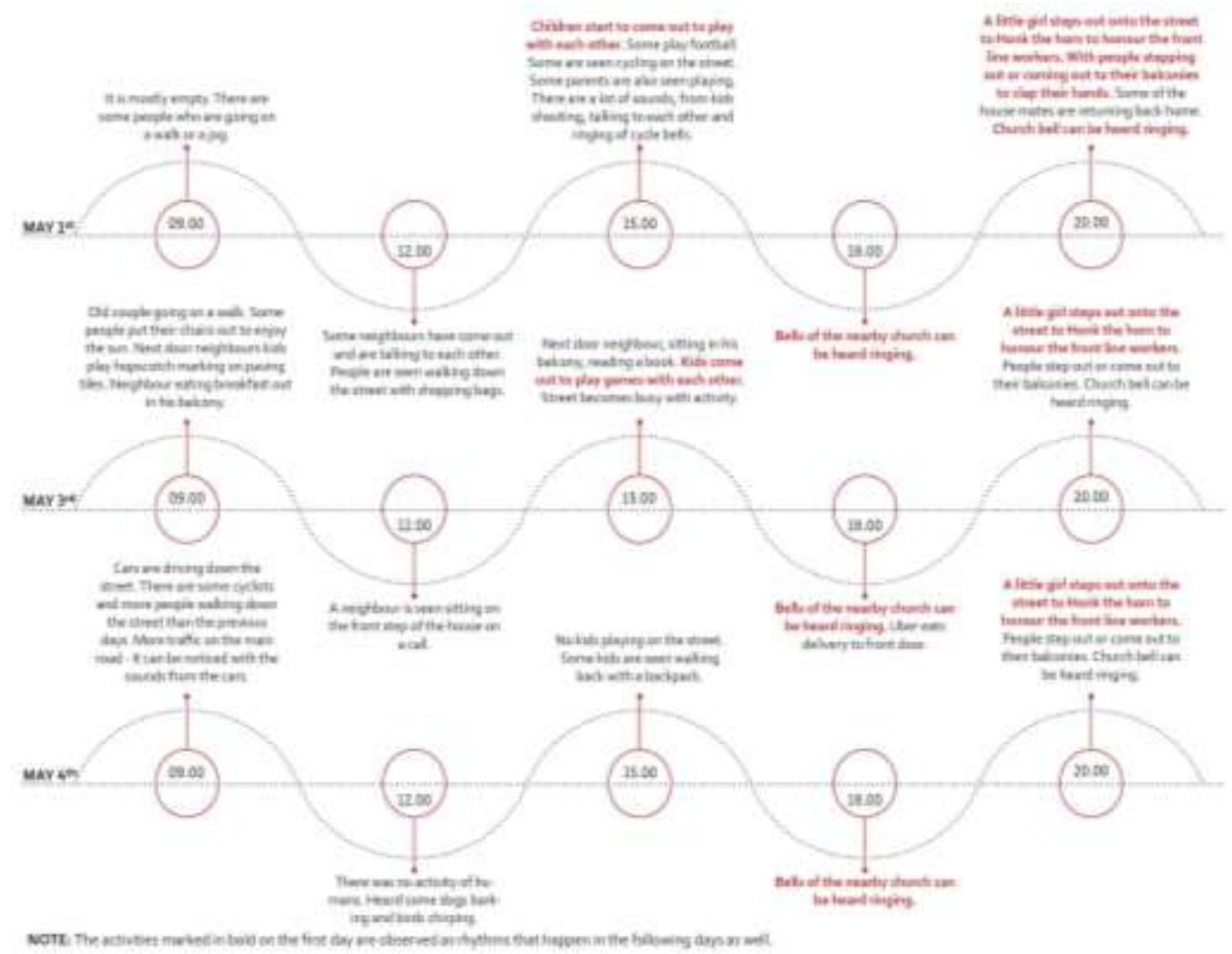

Fig. 3: Views from Balcony Timeline Source: Vasudevan, M. (2020) 


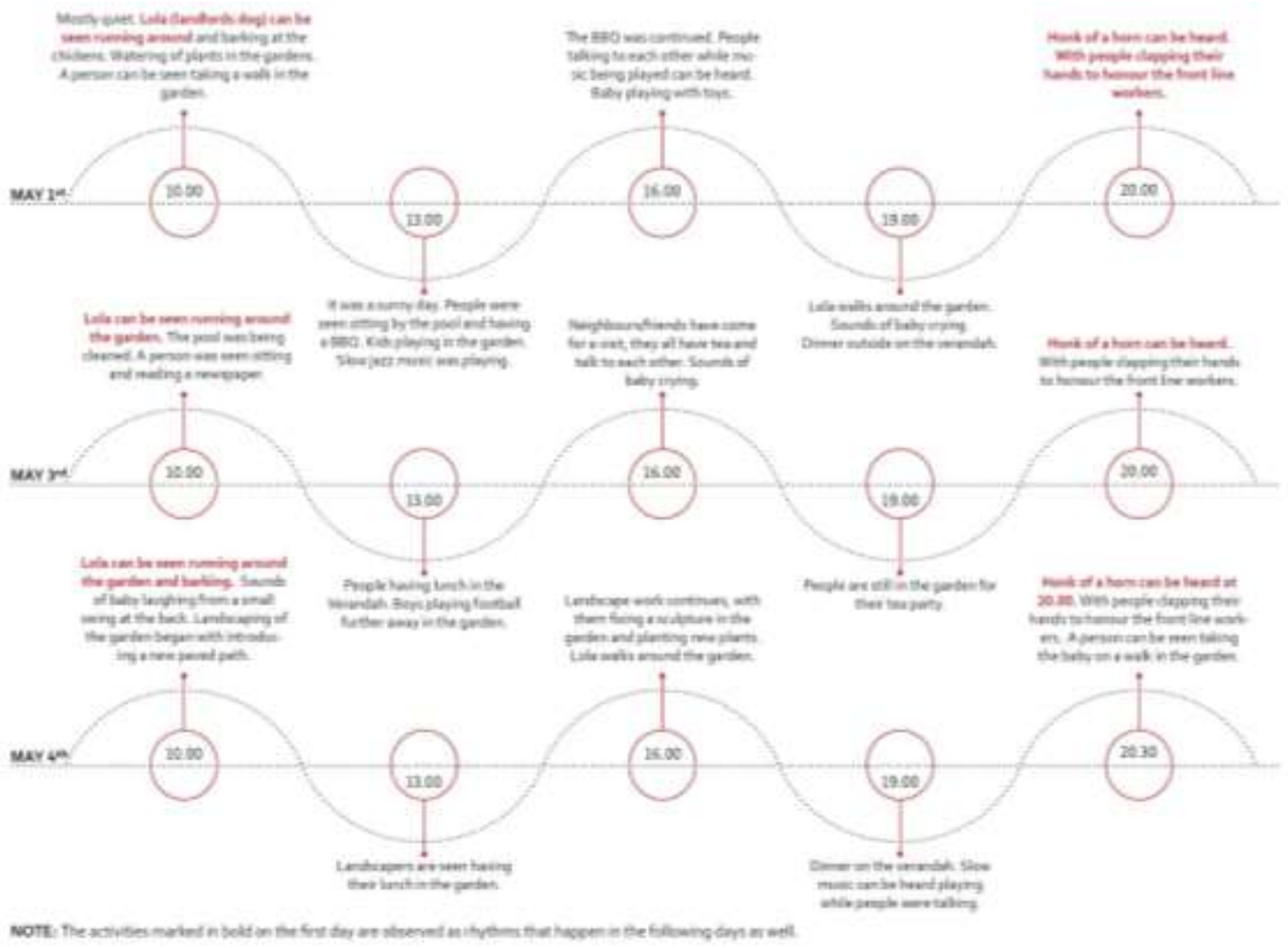

Fig. 4: Views from Window Timeline

Source: Vasudevan, M. (2020)

Just as Lefebvre pointed out: patterns can be observed even when the street gets chaotic. As shown in the timelines above (Fig. $4 \& 5$ ), there are times when the streets or the neighbourhood are empty and quiet and at certain moments of the day it overflows with activity. Although some rhythms could be noted, perhaps a more interesting observation is the difference in the intensity of activities that take place throughout the day. Without planning, some sort of pattern appears, for example, in the lull of activity in the morning or quiet activity in the garden, followed by more eventful gatherings in the latter part of the day which slowly die down with the night.

\section{- Sonya's observations in Schaerbeek}
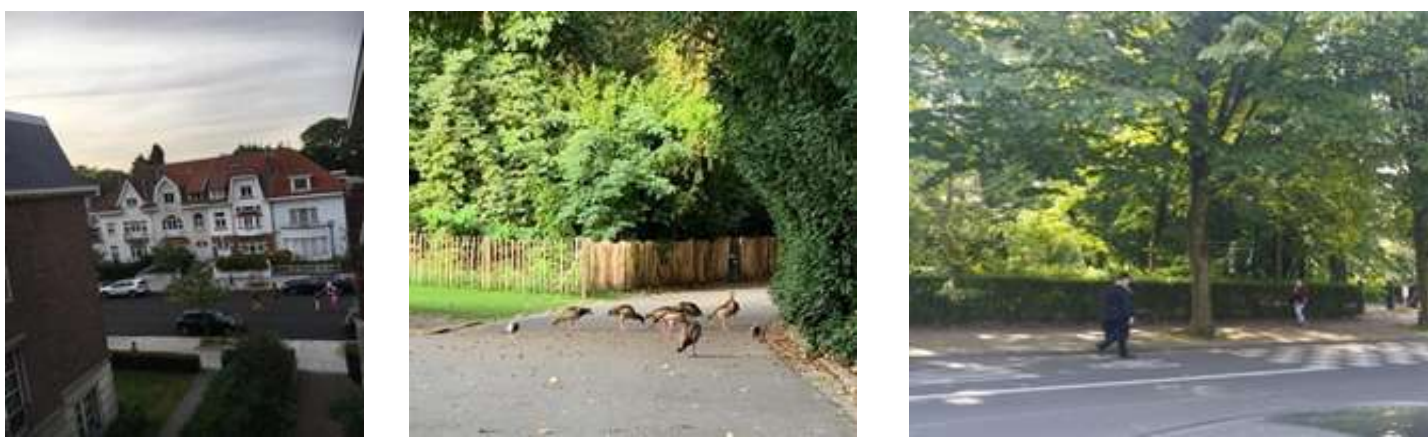

Fig. 5: Views observed from balcony (right), in the park (middle) and on the walk (left). Source: Nanayakkara, S.M. (2020) 
Sonya conducted her observations and analysis from her room's balcony and during a daily two-kilometre walk. The observations from the balcony were conducted during a course of three days (Fig.5) for duration of 10-30 minutes, 5 times a day. For Sonya the balcony was a special kind of platform that allowed for prolonged observations, which aided in bringing to light intangible observations. It led to the realization that, in the absence of vehicular activity and the daily hustle of human activity, other sounds had the ability of manifesting themselves. The birds could be heard making the first sound of the day, not a car alarm or the sound of a horn blaring. (Fig.6)

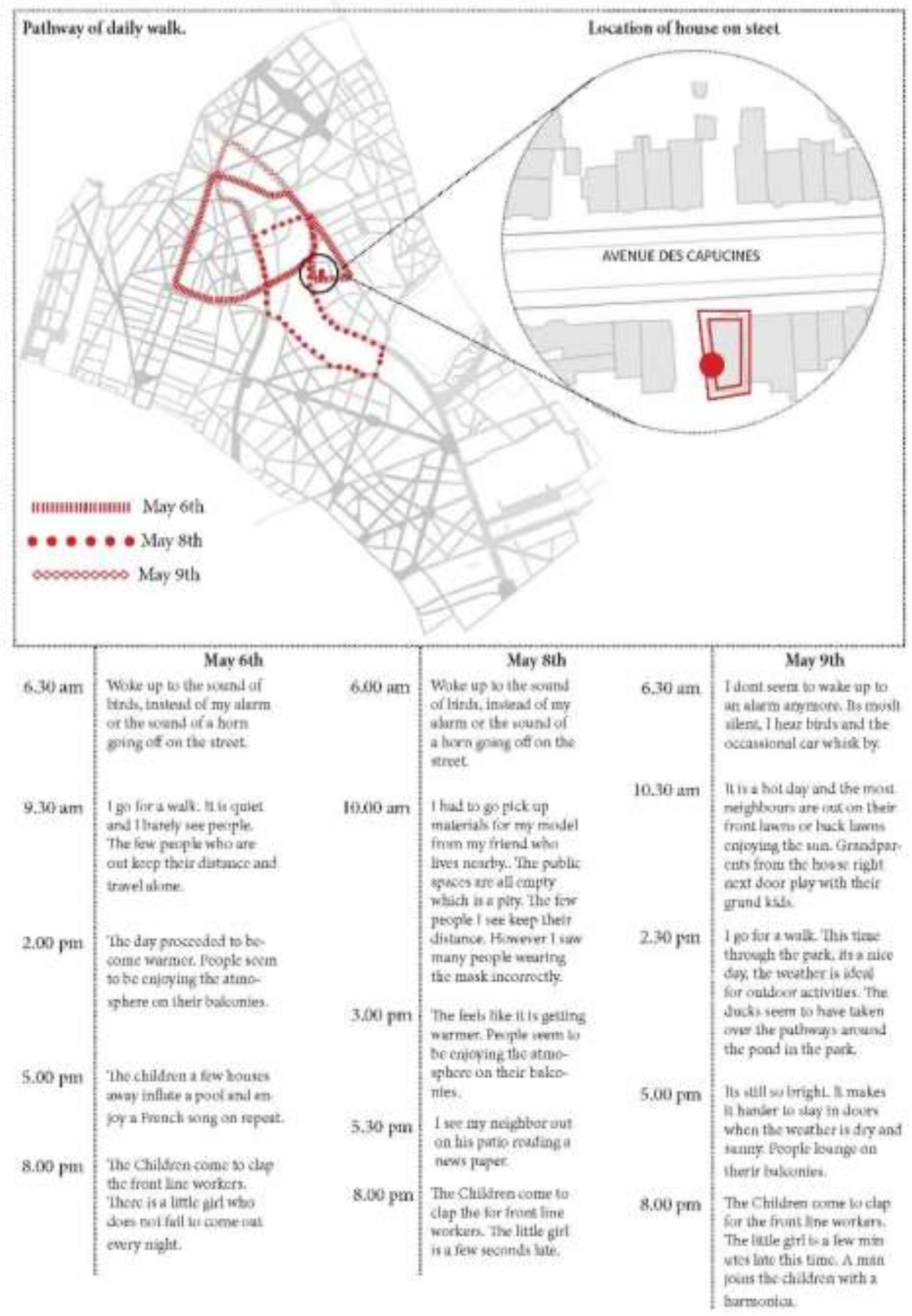

Fig. 6: Views from Balcony Timeline

Source: Nanayakkara.M.S. (2020) 
At the beginning of the confinement period, Sonya observed that people from the neighbourhood stayed indoors and used their gardens as an outdoor 'safe'-zone. However, as confinement kept dragging on, this activity spilled out into the car-free streets, which became a meeting place for children, adults and even pets (Fig. 5). This phenomenon was interesting to observe as it seemed to emerge from a combination of the fatigue of staying in-doors and the sunny weather. Talks with her Belgian landlord and Belgian housemates helped clarify this. As the lockdown measures in Belgium allowed for essential travel within a given perimeter of one's home, Sonya introduced a walk around her neighbourhood to achieve a broader perspective on the activities observed from her room. The walk allowed for another kind of observation, one where she was able to see the daily movement of people and their attempt to make the most of the limited freedom of outdoor activity 'the new normal' while respecting physical distancing. She observed that since there were hardly any people out on the street, animals had now come out to roam around. The people who did take to the street however, were respectful of the measures and practiced physical distancing (Fig.5). There was a general silence that allowed for other sounds of the city to manifest themselves, the squares were empty.

\section{- Rishika's observations in quarantine in Negombo}

Rishika returned to Sri Lanka on the $3^{\text {rd }}$ May in one of the repatriation flights from London due to her parents' overwhelming safety concerns. Returning home implied a mandatory 14 days quarantine. She stayed in a hotel turned quarantine centre under military administration. Though she had visited the hotel before, visiting it under the current circumstances felt strange and unfamiliar. On the journey from the airport to the quarantine centre, the streets which usually would be abundant with the sight of tourists were now totally deserted. The recollection of the area catering for tourists persisted throughout her observation of life outside the window of the hotel where she was quarantined.

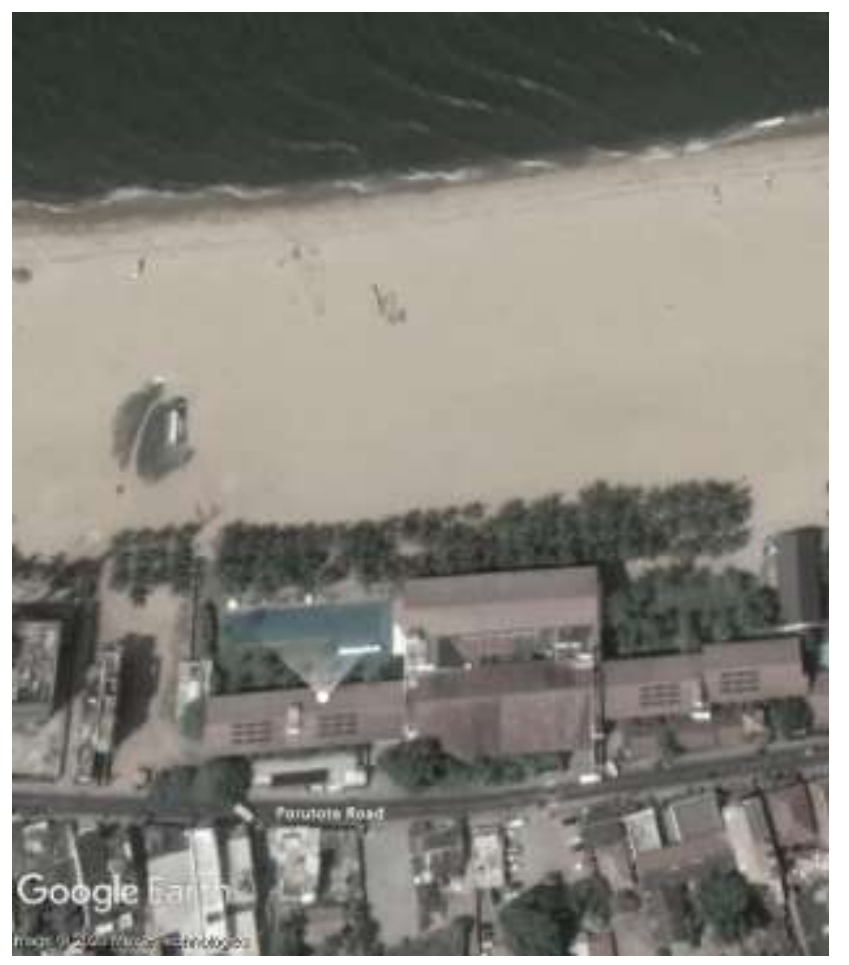

Fig. 7: Hotel on Porutota Road, Negombo, Sri Lanka, where Rishika conducted her observations. Source: Google Earth 
Table 4: Observations 'As seen from my window' in quarantine. Source: Mendis, R.M. (2020)

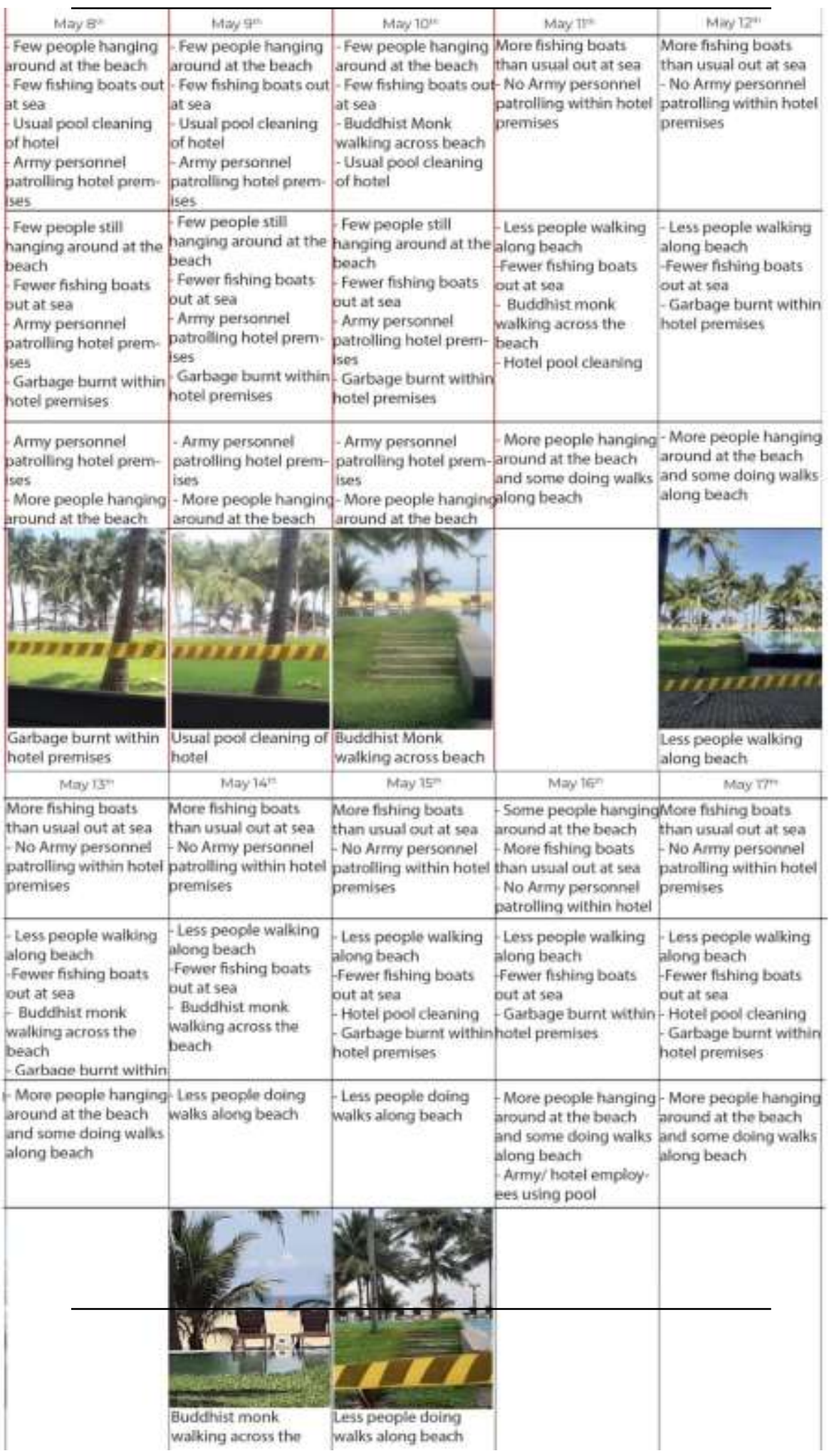


The $8^{\text {th }}$ of May was a national holiday to celebrate a Buddhist festival called Vesak. In usual times, this would have been a bright light-filled festival in Sri Lanka with Lanterns and Pandols decorating the streets. Less people would be walking across the beach as they would be in the temple, at home, or out on the streets spectating the decorations. The hotel would also have decorated its premises and held a Vesak day special. However, she observed no sign of Vesak being celebrated from her window.

Despite curfews, there were still some people loitering on the beach. She assumed they were living nearby as they would not have had to travel far and risk getting apprehended by authorities. Once curfews were lifted by $11^{\text {th }}$ May, the number of fishing boats out at sea increased but the number of day-time visitors on the beach diminished as people assumedly went out to purchase essential goods or back to their jobs. By sundown, people started returning to the beach, presumably after work. She also sighted a Buddhist monk walking across the beach on different days. She wondered if this was his daily stroll, or perhaps this was his secret route to go shopping during lockdowns?

On the $14^{\text {th }}$ and $15^{\text {th }}$ May, she noted an unusually low number of people walking across the beach during the evening. Perhaps this was due to the re-opening of liquor stores so that people chose to purchase and leisurely enjoy a drink or two at home. However, the curfews were in place once more, and a number of people on the beach returned to the usual.

Whilst the typical daily activities of the hotel had changed the cleaning of the swimming pool continued at normal frequency throughout the first week. However, by the second week the hotel management reduced the frequency and it was cleaned at random as no guests were allowed to use it. The regimen of army personnel patrolling the grounds also lessened as they would have realised that the quarantined guests were not interested in violating the rules. The burning of garbage in the afternoon continued everyday within the hotel premises. On the $16^{\text {th }}$ of May, after all the PCR tests of the people quarantined in the hotel came back negative, hotel employees and army personnel decided to take a dip in the pool.

\section{- Comparison and conclusion of the three findings}

The three sets of observations explored the task in the best possible way under the circumstances. Whilst Mahishini and Sonya complemented the observations in Brussels from their room's window with observations with walks in public domain, Rishika was far more restricted in her movements while in quarantine in Negombo. Not being allowed to leave her room, she had to link her observations to assumptions that she could only verify through online conversations with friends and family.

The two students in Brussels deduced that an outdoor or public space, even as little as a balcony, was almost like a lifeline for the inhabitants of the city during the confinement period. Conversations with their landlord and neighbours confirmed that Belgian residents anticipated this period of 'sun' almost the whole year and were now frustrated that they did not get to enjoy the full benefit of it. Hence, the only way to enjoy this sunny period was to use the streets and any open space, while observing physical distancing. Observations also confirmed that the children much anticipated the communal applause for the health-workers. This was the highlight of their day. It was also a moment that livened up the rest of the neighbourhood.

Another interesting observation was how people re-purposed the streets and pavements into a place of unusual activities, where the activity changed according to the circumstance. The streets turned into a playground in the eyes of children and a meeting place in the eyes of adults. In all three cases, the new found rhythms of life under lockdown became almost non-existent as soon as the lockdown was lifted and people slowly began to return back to normalcy. Rhythmanalysis thus proved an effective tool to understand the rhythms and patterns of everyday life of people when forced to stay indoors. 


\section{Social media usages bridging the physical distance between the BCR and Colombo}

The Covid-19 confinement changed the lifestyle and patterns of everyday life of all inhabitants of Belgium, irrespective whether they were born and raised in Belgium or foreignborn. Many had to get accustomed to the increased usage of social media as a way of communication for their daily interactions. As for the selection of respondents in this exercise, the sole criterion was that they had to be fellow country(wo)men of the student conducting the rhythmanalysis and that they were residing in the BCR throughout the period of confinement.

Table 5: Comparative Overview of Respondent Profiles and Data Collection Methods

\begin{tabular}{|c|c|c|c|}
\hline Feature & \multicolumn{3}{|l|}{ Respondent's Profile } \\
\hline & Respondent A (Mahishini) & Respondent B (Sonya) & Respondent C (Rishika) \\
\hline Age & 29 & 25 & 24 \\
\hline Gender & Male & Female & Male \\
\hline Origin & Colombo & Colombo & Colombo \\
\hline Languages & $\begin{array}{l}\text { English, Sinhala, Tamil, French } \\
\text { (passive), Dutch (learning) }\end{array}$ & English, Sinhala, Dutch, German & English, Tamil, Sinhala \\
\hline Family & Father, mother, younger brother & $\begin{array}{l}\text { Father, mother In Sri Lanka, brother } \\
\text { in Amsterdam, uncle and aunt in } \\
\text { BCR }\end{array}$ & $\begin{array}{l}\text { Father, mother, twin sister, younger } \\
\text { sister }\end{array}$ \\
\hline Time in BCR & 8 months & 8 months & 8 months \\
\hline Occupation & Master Student @ KU Leuven & $\begin{array}{l}\text { Research Assistant @ South Asia } \\
\text { Democratic Forum }\end{array}$ & Master student @ KU Leuven \\
\hline $\begin{array}{l}\text { Relation to } \\
\text { student }\end{array}$ & Friend of a friend & $\begin{array}{l}\text { Became acquainted at a function at } \\
\text { the Sri Lankan Embassy }\end{array}$ & Friend of a friend \\
\hline $\begin{array}{l}\text { Current living } \\
\text { conditions }\end{array}$ & $\begin{array}{l}\text { Living with } 8 \text { others from } \\
\text { different countries }\end{array}$ & Living with 8 other housemates & Living with 2 other flatmates \\
\hline $\begin{array}{l}\text { Modes of BCR } \\
\text { transportation }\end{array}$ & $\begin{array}{l}\text { Walk \& public transport, } \\
\text { sometimes bicycle }\end{array}$ & Walk \& public transport & Walk \& public transport \\
\hline Hobbies & Running, walking and Cooking & $\begin{array}{l}\text { Travelling \& outdoor activities (e.g. } \\
\text { surfing, hiking, camping) }\end{array}$ & Football, running \& reading \\
\hline \multirow[t]{2}{*}{ Method } & \multicolumn{3}{|l|}{ Data mining \& processing } \\
\hline & Respondent A (Mahishini) & Respondent B (Sonya) & Respondent C (Rishika) \\
\hline $\begin{array}{l}\text { Daily data } \\
\text { logging }\end{array}$ & $\begin{array}{l}\text { Friday } 1^{\text {st }} \text { May, Sunday } 3^{\text {rd }} \text { May, } \\
\text {,Monday } 4^{\text {th }} \text { May }\end{array}$ & $\begin{array}{l}\text { Friday to Sunday 8th May } 2020- \\
\text { 10th May } 2020\end{array}$ & $\begin{array}{l}\text { Friday to Sunday 8th May } 2020- \\
\text { 10th May } 2020\end{array}$ \\
\hline Open interview & Yes & Yes & Yes \\
\hline Other (specify) & $\begin{array}{l}\text { Respondent was requested to } \\
\text { log a table of their activities. } \\
\text { Additional information and } \\
\text { broader understanding of the } \\
\text { respondent's experience was } \\
\text { established through follow-up } \\
\text { Interviews }\end{array}$ & $\begin{array}{l}\text { The respondent was requested to log } \\
\text { in their activities whenever time } \\
\text { permitted them over the course of } \\
\text { three days that was decided prior to } \\
\text { the observation period. }\end{array}$ & $\begin{array}{l}\text { Respondent was requested to fill two } \\
\text { tables prepared by author to log } \\
\text { hourly activities during three days. } \\
\text { One for daily activities during } \\
\text { COVID-19 and other to recollect } \\
\text { activities before COVID - } 19\end{array}$ \\
\hline
\end{tabular}

Due to the confinement restrictions and physical distancing, the three students had to collect primary data by online means only. They sought to trace the activities that the tree Sri Lankan respondents conducted over the three days indicated in Table 3. Each researcherrespondent pair subsequently discussed the raw data so as to arrive at a classification following Lefebvre's into 'rhythms of the self', 'endogenous rhythms' and 'external rhythms'

\section{- Respondent A: 29-year-old male from Colombo, studying a Master in Civil Engineering at KU Leuven}

Mahishini's respondent was a Master's student studying in Brussels. He was also doing an internship at a start-up company which required him to contact potential investors. Both these situations required that the respondent had to spend most of his time online through various social platforms.

Discussions with respondent A revealed that he had experienced an active student life participating in various socio-cultural celebrations prior to coronavirus. Under the current circumstances, however, zoom parties have turned out to be interesting replacements. The timeline 
in Figure 8 shows the different socio-cultural rhythms that the respondent would have followed before Covid-19. Since these events got cancelled, the resulting mode of the rhythms celebrated is very much different. Events ranging from family gatherings to church services turned into online based celebrations. This shift to online participation so as to continue celebrating socio-cultural rhythms, can be perceived as an attempt to fulfil the urge to 'get out' of confinement.

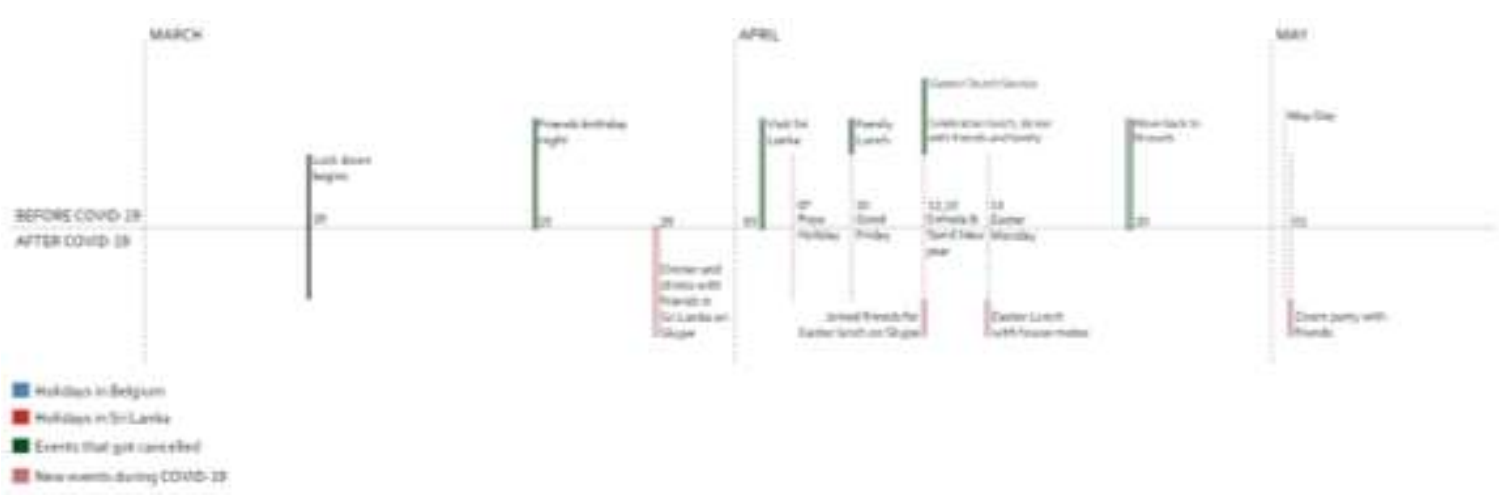

Fig. 8: Respondent A's activities before and after Covid-19 confinement Source: Vasudevan, M. (2020)

The detailed three-day observation of respondent A's daily activities confirms that the Covid-19 pandemic forced him to make some necessary changes to his life which he began to embrace in the following months. It gave him an opportunity to expand his way of thinking and to involve intensely in physical activities, which helped him overcome the fatigue of staying indoors.

As shown in Table 6, the longer respondent A spent in lockdown, the more time he spent on social media for relevant university work with his colleagues and for his part time job by engaging in Skype and Email. He also spent more time communicating with his family and friends in Sri Lanka due to the ever-growing concern about the pandemic. 
Table 6: Respondent's diary: Daily activities and social media usage analysis Source: Vasudevan, M. (2020)

\begin{tabular}{|c|c|c|}
\hline Timer & Nowhty & 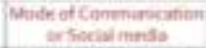 \\
\hline neo an & 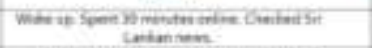 & 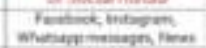 \\
\hline assam & 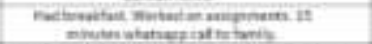 & Wheraw \\
\hline taso am & 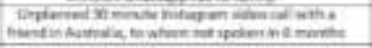 & nitapin \\
\hline $11.30 \mathrm{am}$ & 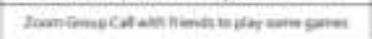 & Tation \\
\hline $2.00 \mathrm{pm}$ & 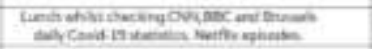 & 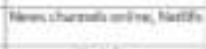 \\
\hline $600 \mathrm{pm}$ & 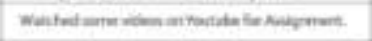 & $\sin$ \\
\hline $5.30 \mathrm{~mm}$ & 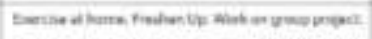 & $n=0$ \\
\hline 7.20 pm: & 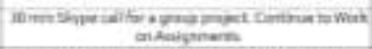 & 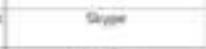 \\
\hline scepm & 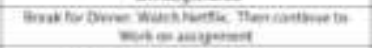 & Wuth: \\
\hline $330 p=$ & Asompenty unt unmetiventh & $8 \mathrm{mon}$ \\
\hline $20 \times 0$ pm & 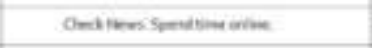 & 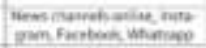 \\
\hline $1200 \mathrm{am}$ & Secthre. & $\tan$ \\
\hline
\end{tabular}

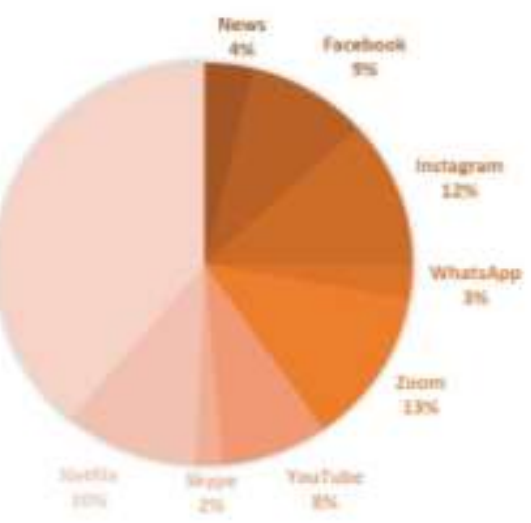

\begin{tabular}{|c|c|c|}
\hline Nen: & Anaily & 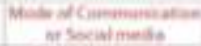 \\
\hline $3,00=0$ & 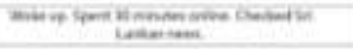 & frove inusyen \\
\hline ryour & 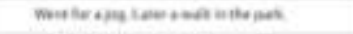 & $=$ \\
\hline 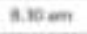 & 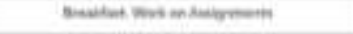 & valsism \\
\hline $1000 \mathrm{kn}$ & 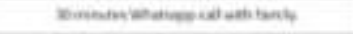 & Whaneser \\
\hline 12.00pon & 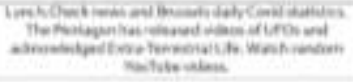 & 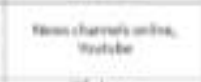 \\
\hline $2.00 \mathrm{pm}$ & 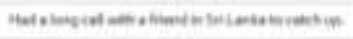 & Nhaneser \\
\hline Nopen & 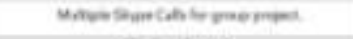 & Were \\
\hline Sxipm & 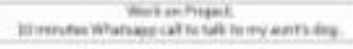 & Whatians \\
\hline s.0opm & 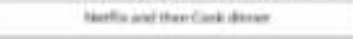 & Rerî́. \\
\hline $200 p m$ & 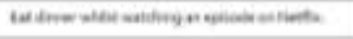 & nients. \\
\hline $10 \mathrm{opom}$ & 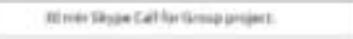 & wan \\
\hline jexpm & 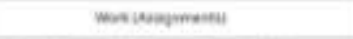 & wase \\
\hline 12.10 an & 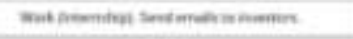 & $t=i$ \\
\hline$x \mathrm{sen} \times m$ & senie & $\sin$ \\
\hline
\end{tabular}

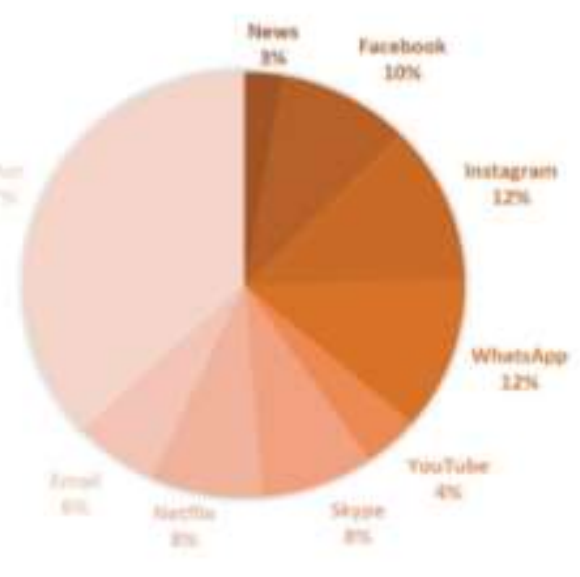

\begin{tabular}{|c|c|c|}
\hline tame & Natially & 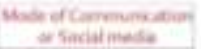 \\
\hline $700 \mathrm{men}$ & 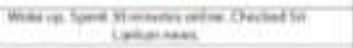 & 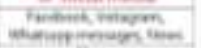 \\
\hline $7.45 \mathrm{~mm}$ & 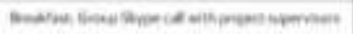 & \\
\hline $3.0 \mathrm{~mm}$ & 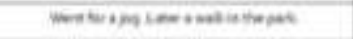 & $\lim 5$ \\
\hline $1100=$ & 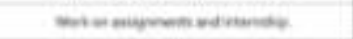 & fimal \\
\hline $0.0 \mathrm{pm}$ & 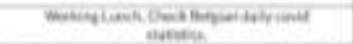 & 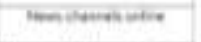 \\
\hline $100 \mathrm{pm}$ & 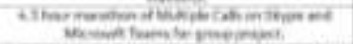 & 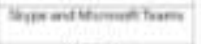 \\
\hline saim & 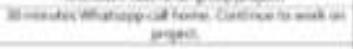 & Whaseat \\
\hline e.60 pm & centions & $\lim =$ \\
\hline $\mathbf{s . 6 p m}$ & 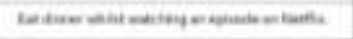 & int. \\
\hline seepm & met indangrient: & theis \\
\hline $12.00=n$ & 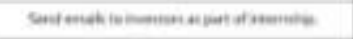 & Emen \\
\hline $200 \mathrm{gm}$ & maties & wer \\
\hline
\end{tabular}

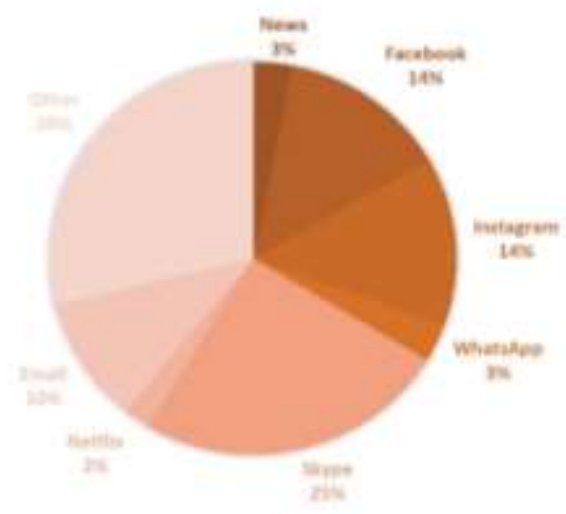


Table 7: Respondent's rhythms categorized Source: Vasudevan, M. (2020)

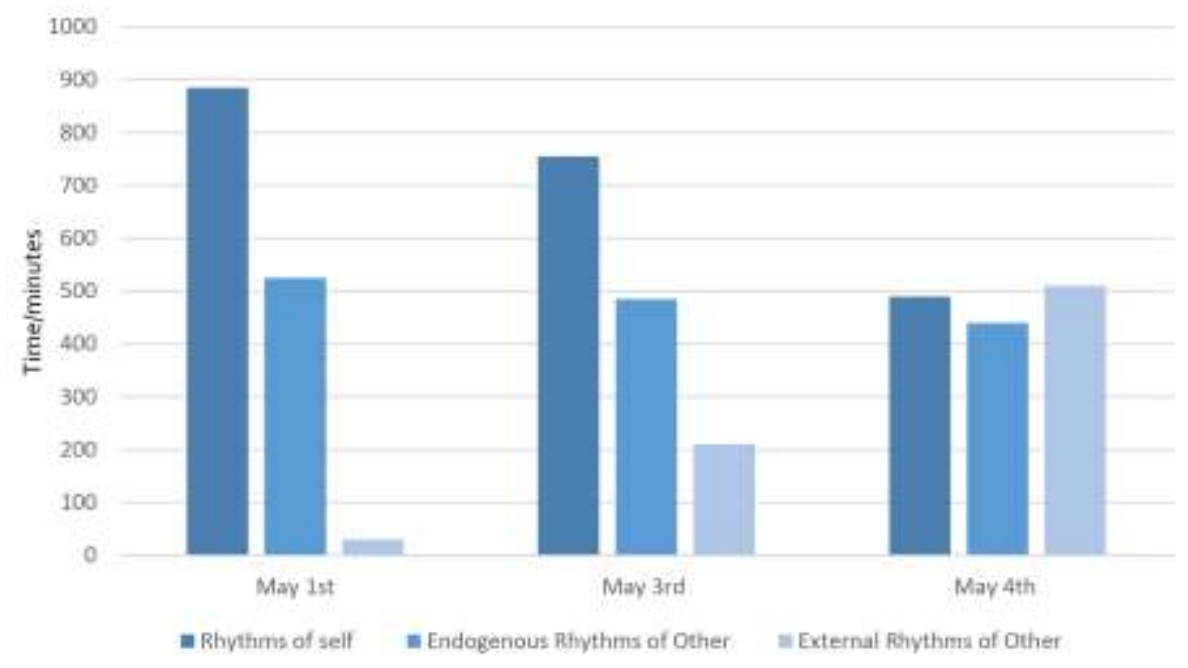

Table 7 shows how respondent A engaged in a range of activities that contributed to his wellness and health, while maintaining a balance in external and endogenous rhythms of others. It shows that the largest amount of time spent in a day would be for himself. Post interview with the respondent indicated that rhythms of self were very important to him amidst the lockdown and that spending a large amount of time on social platforms had forced him to discover newer rhythms of self.

\section{- Respondent B: 25-year-old female from Colombo, research assistant with South Asia} Democratic Forum

Sonya's respondent was a Sri Lankan citizen holding a British passport. She completed her Bachelors in the Netherlands, where her brother lives. Then she moved to Brussels where her uncle, aunt and nephews are living. She does not live with her relatives but with 8 housemates from various countries in a house that is conveniently located within 2 minutes' walk from an essential goods store. The proximity of a park at less than 5 minutes' walk is also an advantage given her preference for outdoor activities.

During a series of conversations, respondent B revealed that the pandemic confinement did not alter her behavioural patterns unreasonably. In fact, the confinement paved the way for her to fine tune and refine her routine in order to create a more productive and fulfilling day.

Respondent B is independent of her parents' economic condition in Sri Lanka. Therefore, she was less concerned about Sri Lankan news and more concerned and up to date with Belgian news platforms. She had cousins nearby whom she met frequently in parks and large open spaces while keeping the required physical distance. Due to the fact that they were all in the same continent during the confinement the respondent was less overwhelmed by the sense of missing home. 
Table 8: Respondent B's diary: Daily activities and social media usage analysis Source: Nanayakkara M.S. (2020)

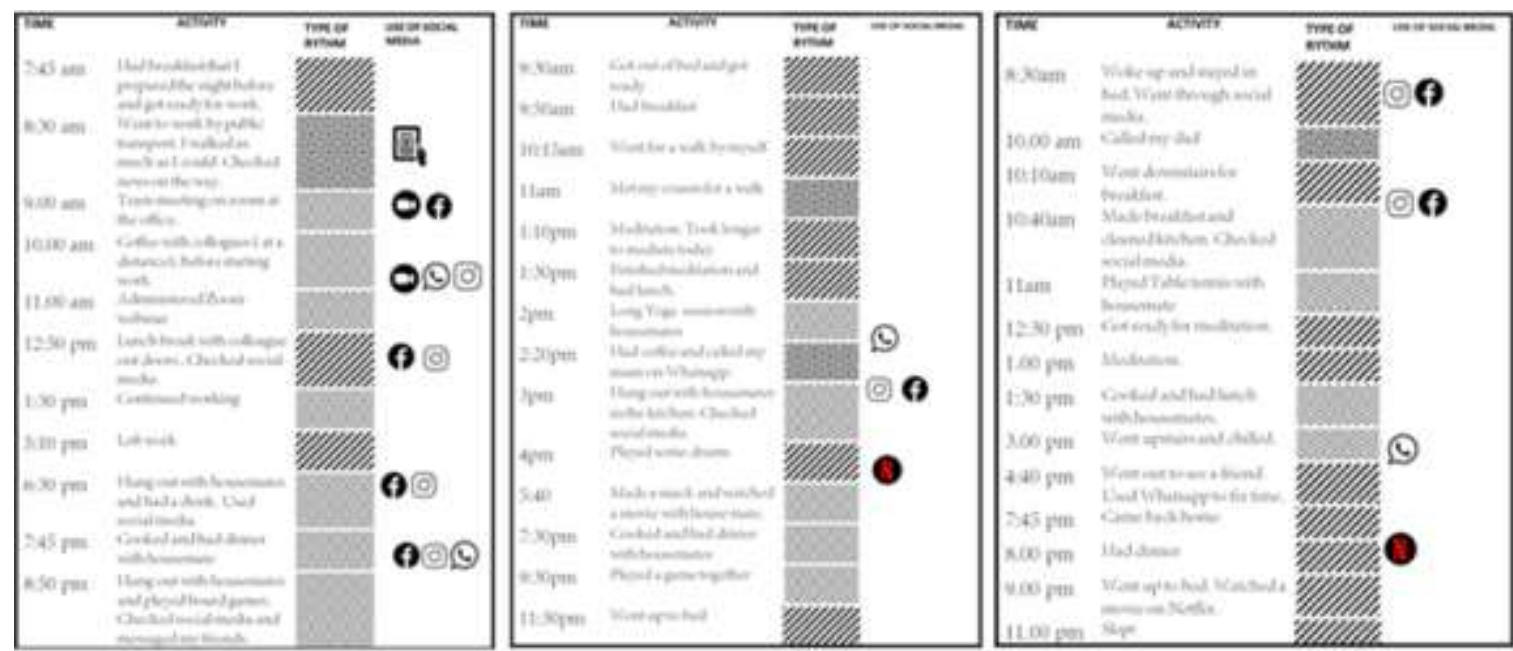

The respondent attended work at the South Asia Democratic Forum five days a week. The reduction in social interactions with her co-workers brought about a certain fatigue in the work environment. Most meetings were conducted through Zoom and the rest through Skype conference calls, which appeared to bring dissatisfaction to her and her co-workers. She also mentioned that she and her housemates had started engaging in activities together since the confinement commenced. They prepared meals together, played board games and began planting herbs in the kitchen for everyone to use.

Table 9: Respondent's rhythms categorized Source: Nanayakkara.M.S. (2020)

\section{Frequency of Respondents Rythms in a day}

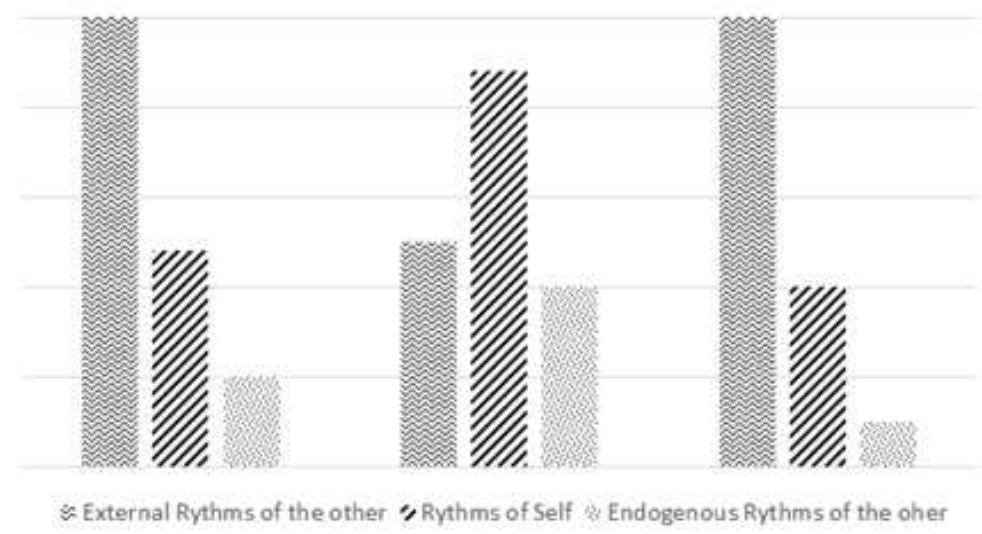

Respondent B stated that she only utilizes the screen when strictly needed. "I am tired of looking at screens for almost two months", she is expressing a kind of fatigue. "Everything is too draggy," she said during a conversation. Despite this screen-fatigue, she calls her parents 
regularly, using WhatsApp and Skype as these are the only platforms her parents are comfortable in using. She also keeps in touch with her friends via Facebook, Instagram and Whatsapp (Table. 8)

The respondent meditates every day. This has been a rhythm of self that she had inculcated within herself, prior to the lockdown. However, she did note that the weekly frequency of these sessions had increased during the confinement. Her sessions were longer too which has brought about faster results.

Taken together, all these refinements of already existing patterns brought a sense of peace and control to her during the time of the pandemic which brought about uncertainty and fear of the future. These changes in an already existing pattern proved to prevail even after the confinement period, which reinforces the initial observations.

\section{- Respondent C: 24-year-old male from Colombo, studying an MBA at KU Leuven}

Respondent $\mathrm{C}$ came to study an MBA in Belgium, with the idea that this would become the centrally located base from which he could visit the rest of Europe. To finance that dream, he soon started doing all kinds of small freelance jobs at the university and outside of it. With the rise of Covid-19, he had to stall those activities and had more time to focus on himself. During the time data gathering was happening, Covid-19 infections in Belgium were still high in comparison to Sri Lanka but the number of cases per day reduced. Belgium soon started opening up and lifting travel bans. Simultaneously, Sri Lanka had started to open special repatriation flights back to the country. Therefore, the activity records of the respondent show that some of his time was spent contacting the Sri Lankan embassy in Belgium to find ways to head back home. 
Table 10: Respondent C's recollection of daily activities and social media usage before COVID - 19 (left) compared to his daily activities and social media usage during COVID - 19(right). Source: Mendis, R.M (2020)

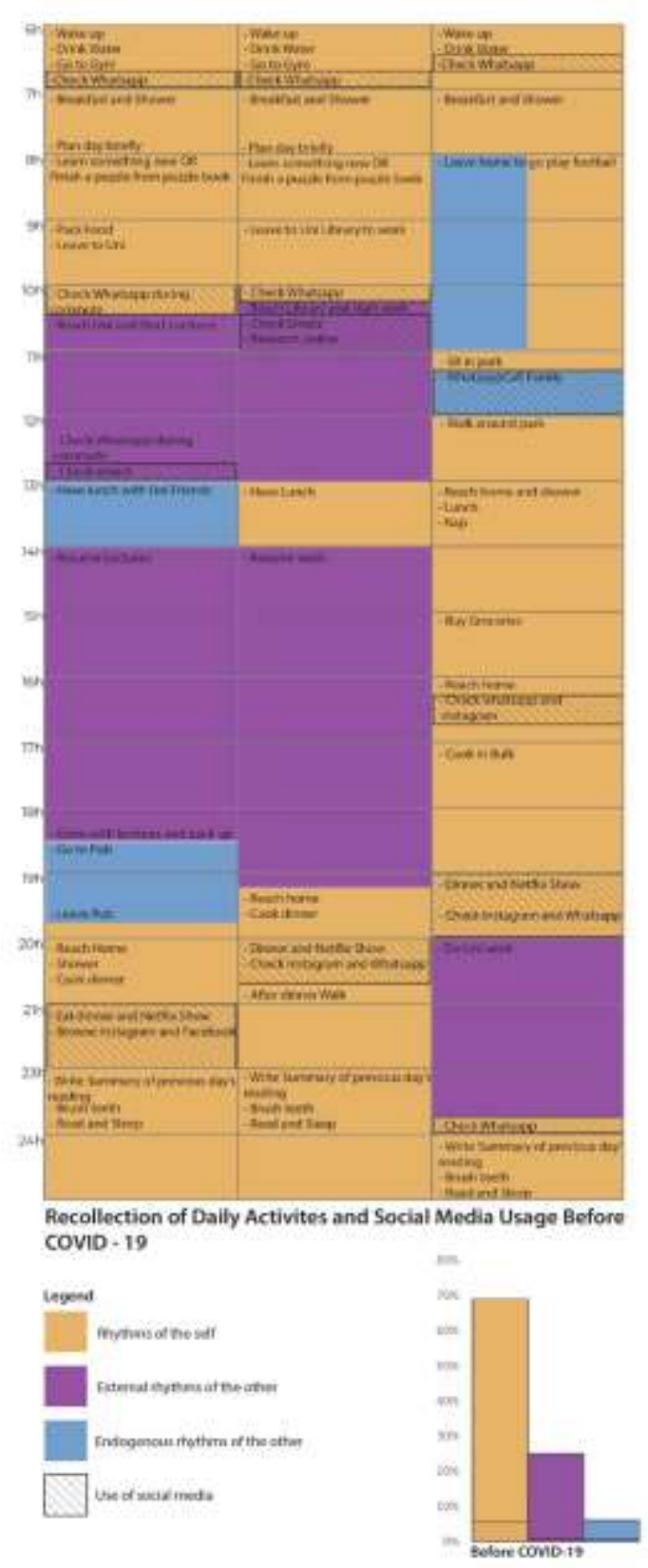

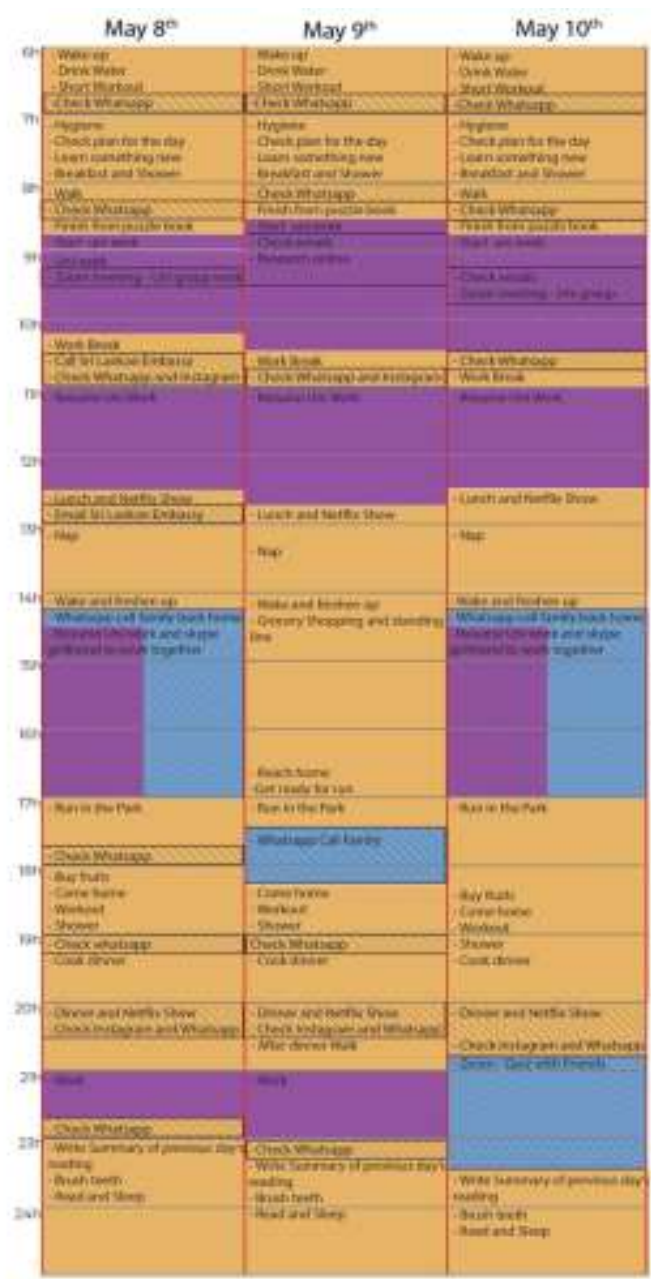

Daily Activites and Social Media Usage During Covi - 19

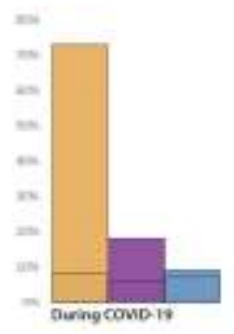

Table 10 shows a comparison of his activities as recollected from before and recorded during confinement. During COVID-19 his 'rhythms of the self' increased slightly as he had more time to focus on himself and his hobbies. Whilst soccer games were not allowed, the frequency of his runs increased to once daily as opposed to once a week before COVID-19. He also had more time to check WhatsApp, scroll through Instagram and watch Netflix. A new rhythm of email correspondence with the Sri Lankan embassy in Belgium emerged during this time to secure a place for himself on a repatriation flight. 
His external rhythms of the other consist of time spent on university-related activities. Despite the reduction in the time spent on university work, social media usage increased, as Skype and Zoom became the means of conducting group work and lectures with tutors.

His endogenous rhythms of the other show an increased frequency in contacting family and friends. Being an independent individual, he used to contact his family once every three days. WhatsApp calls with his family increased to a call a day as concerns of the family grew since the number of Covid-19 cases in Belgium rose remarkably high compared to Sri Lanka. He also used Skype more frequently to video chat with his girlfriend who was also studying abroad. With the help of the Zoom platform, he also moved his weekly quiz night with friends online. The combination of all these online contacts allowed for companionship whilst working from home.

\section{- Comparison and conclusion of the three findings}

The rhythmanalyses of the three students shows that confinement has led to highly similar results among the respondents. First, the rhythms of the self either increased slightly or were greatly refined. Due to the length of the confinement and its restrictions on social interaction, the respondents had time to explore, fine-tune and/or increase rhythms of self. They enhanced physical exercise, meditation and reflection. Second, the internet was used to overcome feelings of loneliness, boredom and isolation. and bridge physical distance and the pandemic confinement. Hence, endogenous rhythms of the other gained more importance. The respondents turned to online communication and social media platforms to reach out to their loved ones and bridge the gap that the confinement and physical distancing had created. Physical gatherings and celebrations were replaced by virtual ones. Third, external rhythms of the other thoroughly changed as they became dominated by virtual communication. Physical distancing compelled many workplaces and academic institutions to adapt virtual spaces for daily work and study. For the respondents, this meant the fast conversion to adopt new software and social media leading to a massive increase in screen time, to the point of creating screen-fatigue.

\section{Final reflections and conclusions}

Belgium and Sri Lanka imposed their measures to prevent the spread of COVID-19 within days of each other. Sri Lanka imposed strict curfews across the island, only lifting them on certain days to allow citizens to shop for essentials. In Belgium, the lockdown measures allowed citizens to step out of their home only for physical exercise and to shop for essentials.

The students observed different public reactions to these measures. In Brussels, they noticed that the usual social rhythms had taken a back seat. New rhythms started to emerge as days passed, with some of these becoming a constant. Platforms such as streets, balconies, and gardens saw new and unusually frequent activity. In Sri Lanka, celebrations such as the annual Vesak festival faced a major disruption. Whereas usually, citizens celebrate by visiting friends and family and celebrations take up streets and squares, the 2020 Vesak festival saw complete quiet and the absence of the traditional collective rhythms.

As could be expected, the respondents' behavior during lockdown showed an increase in digital media usage. Frequently used communication platforms for texting, such as Whatsapp, enhanced endogenous rhythms of others as they were used to connect with concerned families back home. Rarely used digital platforms such as video calling apps gained popularity as they allowed the respondents to continue their work and studies virtually, enhancing external rhythms of the other. Digital media platforms were used for enhancing productivity, gaining knowledge, and self-improvement related to the rhythms of self.

All this indicates that rhythmanalysis offers a valid research tool to track and document changes in life-style despite physical distancing. The fact that both the researching and the researched subjects were going through the same 'lived experience' of confinement in the BCR and far away from home made up for the embodied and sensory quality of rhythmanalysis that got lost in online communication. 
The online modus operandi and the fact that the whole of the BCR was going through the same lockdown situation appears to have lowered - albeit temporarily - the threshold between local and voluntary migrant sections of the population. The overall study confirms Lefebvre's (2004: 44) contention that "[d]isruptions and crises always have origins in and effects on rhythms". It clearly shows that the COVID-19 pandemic shot a "hole in time". The case studies demonstrate that people - voluntary migrants and locals alike - had the resilience not only to adapt to the crisis situation but also to weave creative and inventive rhythms in their daily life.

\section{References}

De Wandeler, K. and A. Dissanayake (2013), 'Rhythmanalysis as a tool for understanding shifting urban life and settings: insights from Brussels and Colombo', in R.Dayaratne and J. Wijesundara (eds.), Cities, People and Places: Proceedings of the International Urban Design Conference, Colombo, Sri Lanka, 14 - 17 October 2013, Department of Architecture, Colombo, pp. 137 153.

De Wandeler, K. (2020), 'Introduction to Rhythmanalysis', Urban Anthropology: Comparative Studies session 9, viewed 19 August 2020, https://p.cygnus.cc.kuleuven.be/bbcswebdav/pid-27059358dt-content-rid-265509868_2/courses/B-KUL-A60213-1920/Urban\%20anthropology\%20201920_session\%209.pdf

Jaulin, R. (1973), Gens du soi, gens de l'autre, Paris: Union Générale d'éditions 10/18.

Lefebvre, H. (1981), Critique de la vie quotidienne III: de la modernité au modernisme (Pour une metaphilosopie du quotidien, Paris: L'Arche.

Lefebvre, H. (2004) [1992], Rhythmanalysis: Space, Time and Everyday Life (Transl.Stuart Elden and Gerald Moore), London; New York: Coninuum.

Lyon, D. (2019), What is Rhythmanalysis?, London: Bloomsbury Academic.

Mendis, R.M. (2020), Rhythmanalysis as a Tool to Examine the Impact of COVID-19 Confinement, individual assignment submitted for the course 'Urban Anthropology: Comparative studies AY 2019-2020'.

Nanayakkara, S.M. (2020), Rythmanalysis, The impact of COVID-19, individual assignment submitted for the course 'Urban Anthropology: Comparative studies AY 2019-2020'.

Sandford, A. (2020), Coronavirus: Half of humanity now on lockdown as 90 countries call for confinement. Euronews, 3 April 2020. Viewed 14 September 2020. https://www.euronews.com/2020/04/02/coronavirus-in-europe-spain-s-death-toll-hits-10-000after-record-950-new-deaths-in-24-hou

Vasudevan, M. (2020), Rhythmanalysis, The impact of COVID-19, individual assignment submitted for the course 'Urban Anthropology: Comparative studies AY 2019-202 